\title{
Wyimki z biografii jezuitów białoruskich
}

\begin{abstract}
Zaledwie rok przed zamknięciem zakonu pewnej nocy dwustu jezuitów położyło się spać w Polsce, a obudziło następnego dnia w Rosji. Nigdzie się nie ruszali, poruszył się pod nimi polityczny grunt. Prusy, Austria i Rosja poczęstowały się kawałkami Polski ${ }^{1}$.
\end{abstract}

Chris Lovney

\section{„Radość” i ,troska” - ucieczka - rok 1812}

W słynnej Pieśni IX. „Nie porzucaj nadzieję” (z Ksiąg wtórych) Jan Kochanowski pisał:

Nic wiecznego na świecie:

Radość się z troską plecie,

A kiedy jedna weźmie moc nawiętszą,

Wtenczas masz ujźrzeć odmianę naprędszą ${ }^{2}$.

Doskonałą ilustracją zawartej w zacytowanym fragmencie tezy są doświadczenia jezuitów białoruskich, szczególnie połockich, związane z wydarzeniami, jakie miały miejsce w lecie 1812 roku. Radością dla Towarzystwa Jezusowego było niewątpliwie zakończenie procesu przekształcania Kolegium Połockiego w Akademię Połocką. Uroczystości oficjalnego wręczenia przywileju, przeprowadzone

${ }^{*}$ Dr hab. prof. UR, Uniwersytet Rzeszowski, Wydział Filologiczny, Instytut Filologii Polskiej, Zakład Literatury Staropolskiej i Polskiego Oświecenia, al. Tadeusza Rejtana 16C, 35-959 Rzeszów; e-mail: marekn5@op.pl

${ }^{1}$ Zob. Ch. Lowney, Heroiczne przywództwo. Tajemnice sukcesu firmy istniejącej ponad 450 lat, tłum. L. Malczak, Wydawnictwo WAM, Kraków 2011, s. 260. Ów „koszmarny sen” dotyczył 201 zakonników, w tym 97 księży z zaboru rosyjskiego, a ok. 1000 zakonników (łącznie) zamieszkujących tereny oderwane od Rzeczypospolitej po pierwszym rozbiorze.

2 J. Kochanowski, Pieśń IX z Ksiag wtórych, w: tegoż, Pieśni, wstęp i oprac. L. Szczerbicka-Ślęk, wyd. 6, Zakład Narodowy im. Ossolińskich - Wydawnictwo Polskiej Akademii Nauk, Wrocław 2008, BN I, nr 100, s. 79. 
w oprawie religijnej, miały miejsce 15 czerwca 1812 roku. Aż sześć miesięcy jednak, do 8 stycznia 1813 roku, przyszło oczekiwać nauczycielom i studentom tej placówki akademickiej na zainaugurowanie działalności administracyjno-dydaktycznej. Wydarzenia polityczne pokrzyżowały bowiem plany przywódcom i członkom Towarzystwa Jezusowego. Otóż w parę dni po otwarciu uczelni jezuici opuścili Połock. Jak twierdzi Stanisław Załęski, z całej obsady zakonnej w czasie kampanii moskiewskiej Napoleona w mieście pozostało zaledwie trzech księży: Antoni Lustyg (Lustig) (1752-1815) - pierwszy rektor Akademii Połockiej (1812-1814), urodzony w Langres we Francji Dezydery Richardot (1769-1849) oraz pochodzący z Nowogródka Wincenty Czarnyszewicz (1782-1832) .

Ignacy Loyola, twórca zakonu i reguły, w Ćwiczeniach duchownych, wydanych po raz pierwszy w Rzymie w 1548 roku, domagał się od swoich „synów” skuteczności w dostosowywaniu się do szybko zmieniającego się świata i zachowywania duchowej harmonii, nawet jeśli wokół szaleje piekło. Idealny jezuita w jego wyobrażeniu „miał jedną nogę podniesioną”, zawsze był gotowy zareagować odpowiednio na zaistniałą sytuację naruszającą porządek rutyny i przyzwyczajeń. Loyola podkreślał też konieczność osobistej i zbiorowej sprawności, potrzebę elastyczności i otwartości na nowe pomysły, bezzwłoczności i szybkiego reagowania. Równocześnie zachęcał do stoickiej apatii, obojętności na miejsca czasowego pobytu i stan zakonnego posiadania. Przywiązanie tego rodzaju mogło być przeszkodą w adaptacyjnych wymogach podyktowanych dynamiką zmian historycznych i cywilizacyjnych ${ }^{4}$. Idealny jezuita nie zamykał się więc przed światem, żyjąc w ciągłym ruchu i ową rzeczywistość poczytując za „najspokojniejszy i najprzyjemniejszy dom”. Jak pisał John J. O’Malley SJ, dzięki podróży „świat staje się [jego] domem"'. Tym samym dla zakonnika jezuickiego formą zadomowienia był ciągły ruch i aktywność (nawet w sytuacji dyskomfortu), co odpowiadało po trosze ideałom szkoły humanistycznej reprezentowanej przez Erazma z Rotterdamu, którego uczniem w pewnym sensie był Loyola, podkreślający potrzebę nawiązywania przez jezuitów kontaktów ze światem, ludźmi inaczej myślącymi, zarówno gdy idzie o ideologię, jak i religię.

${ }^{3}$ S. Załęski SJ, Historia zniesienia jezuitów w Polsce i ich zachowanie na Białej Rusi, t. 2, Lwów 1875, s. 368.

${ }^{4}$ Zob. Ch. Lowney, dz. cyt., s. 36-38 [fragment pt. Pomysłowość: „caly świat stanie się naszym domem"].

${ }^{5}$ J. J. O’Malley SJ, To Travel to Any Part of the World: Jerónimo Nadal and the Jesuit Vocation, "Studies in the Spirituality of Jesuits 16" 1984, nr 2, s. 8, cyt. za: Ch. Lowney, dz. cyt., s. 158. Zob. też S. Litak, Jezuici na tle innych zakonów męskich w Polsce w XV-XVIII wieku, w: Jezuici a kultura polska. Materiaty sympozjum z okazji Jubileuszu 500-lecia urodzin Ignacego Loyoli (1491-1991) i 450-lecia powstania Towarzystwa Jezusowego (1540-1990), Kraków, 15-17 lutego 1991 r., pod red. L. Grzebienia SJ, S. Obirka SJ, Wydawnictwo WAM, Kraków 1993, s. 186; Skarb Kościoła. „Ćwiczenia duchowe” w praktyce, praca zbiorowa pod red. T. Hajduka SJ, Wydawnictwo WAM, Kraków 2000. 
Twórca Towarzystwa podkreślał ponadto, że jedną ze skutecznych metod osiągania celów jest wyważony oportunizm i ostrożność, ciche - rzeczywiste lub pozorne - dostosowanie się do zaistniałej sytuacji i okoliczności. Zalecał wycofywać się z konfliktu w oczekiwaniu, iż sprawy uporządkują się same, bez uczestnictwa jezuitów. Myśl tę podjął na kilka tygodni przez rozpoczęciem kampanii napoleońskiej generał zakonu Tadeusz Brzozowski, gdy w liście z 26 kwietnia do prowincjała Alojzego Landesa apelował o powściągliwość i rozsądek, o powstrzymywanie się od komentarzy politycznych na temat aktualnych wydarzeń, zarówno w korespondencji, diariuszach i kronikach, jak i w rozmowach. Ponieważ zakonnicy jezuiccy składali ślub posłuszeństwa Bogu reprezentowanemu przez przełożonych, ten nakaz był w zasadzie respektowany, co rzeczywiście pozwoliło im na pewien czas skutecznie działać na terenie imperium rosyjskiego, a od 1814 roku - na całym świecie.

Zdarzały się wszakże wyjątki. W wierszach Józefa Morelowskiego z lat 1804-1816 wyraźnie dochodzą do głosu uprzedzenia i sympatie polityczne, które, jak można się domyślić, podzielała większość jezuitów działających w państwie carów. Polaryzacja stanowisk wobec „,esarza Francuzów” i „Tytusa Północy” jest w takich choćby utworach jak Pieśn 22. Z okoliczności wojny Rosjan z Napoleonem, Pieśń 5. Na pochwałe Najjaśniejszego Imperatora Aleksandra, Pieśn 19. Nieludzkość tego wieku, Pieśń II. O używaniu bogactw, Do ksiegi ${ }^{6}$ itd. wyraźna i oczywista: Napoleon I oszukał Polaków walczących pod sztandarami francuskimi, łamał traktaty, internował Piusa VII - najpierw we Włoszech, a następnie w Fontainebleau, zlikwidował Państwo Kościelne, usunął w 1806 roku jezuitów z Neapolu, wbrew treści edyktu papieskiego z 30 lipca 1804 roku o przywróceniu ich w Królestwie Obojga Sycylii, Aleksander I natomiast powołał Akademię Połocką, troszczył się o losy Towarzystwa Jezusowego, nadał Polakom konstytucję, zwyciężył „elbskiego wszędobyła” (Do księgi) etc. W sukurs tym wyliczeniom szły subiektywne oceny. Tego pierwszego Morelowski nazywa tyranem, prześladowcą, najeźdźcą, uzurpatorem, szaleńcem, bezbożnikiem, burzycielem porządku i pokoju, zbrodniarzem, cara zaś - dobroczyńcą, tym, który rozsławił Słowian w całej Europie, obrońcą i orędownikiem zakonu, krzewicielem sztuk i nauk, najbardziej światłym władcą Rosji etc. Polaryzację ocen wzmacniała pamięć o wydarzeniach sprzed kilkudziesięciu lat. Oświecenie francuskie, którego pokłosiem był także ruch napoleoński, doprowadziło do rozwiązania zakonu i do jego wieloletnich kłopotów administracyjno-organizacyjnych. Znalazł się on także pod szczególnym obstrzałem ciętego języka, wyostrzonej inteligencji i sprawnego argumentowania Woltera i innych encyklopedystów, twierdzących, że tylko jezuici dysponują odpowiednim zapleczem intelektualnym pozwalającym im skutecznie

${ }^{6}$ Wiersze Józefa Morelowskiego, wyd. i wstęp oprac. E. Aleksandrowska, Zakład Narodowy im. Ossolińskich - Wydawnictwo Polskiej Akademii Nauk, Wrocław 1983, Zapomniani Poeci Oświecenia, [t. 2]. 
odeprzeć ataki na Kościół katolicki. Podobnie odnosili się do zakonników Towarzystwa ich najwięksi wrogowie - janseniści i masoni. Nadto rewolucja francuska dokonała olbrzymich spustoszeń religijnych i po raz pierwszy na niewyobrażalną skalę zachwiała fundamentami katolicyzmu. Jezuici więc, przynajmniej do 1814 roku kojarzyli Francję i Francuzów jednoznacznie, a przy tym stereotypowo, jako źródło ponad czterdziestoletniej niedoli.

Pamiętać należy przy tym, że w Polsce sytuacja przedstawiała się nieco inaczej niż na zachodzie Europy. Dlatego też przede wszystkim polskim zakonnikom Towarzystwo zawdzięczało ciągłość istnienia i przetrwanie najtrudniejszego w dziejach periodu. Na terenie Rzeczypospolitej jezuici byli raczej ostrożnymi sprzymierzeńcami oświecenia niż jego zaciekłymi wrogami. Oczywiście z wyjątkiem takich indywiduów jak ksiądz Stefan Łuskina. Śmiało można postawić tezę, że oświecenie katolickie zaakceptowało większość idei oświecenia świeckiego, co w Polsce stało się możliwe dzięki aktywności pijarów, jezuitów oraz - korzystających z osiągnięć i rozwiązań tych ostatnich - bazylianów. Doskonale zdawał sobie z tego sprawę Stanisław Trembecki, gdy z pozycji libertyna i stronnika królewskiego oburzał się na rozwiązanie Towarzystwa Jezusowego?:

Kogóż i teraz czułe serce nie zaboli?

Ginie sławna społeczność w ostatniej niedoli,

Roztropna i pobożna, od krwi cudzej czysta,

Nad jej losem powinien westchnąć jansenista.

[...]

Lecz którzy waszą pracą wiernymi zostali,

Dobroczynnego Stwórcę jak ojca kochali.

$[\ldots]$

Synów zaś Ignacego ta sława przed światem,

Tysiąc z nich męczenników, żaden nie był katem.

(Oda na ruinę zakonu jezuitów, $1773^{8}$ )

Wprawdzie decyzja papieża Klemensa XIV uniemożliwiła jezuitom współtworzenie oświecenia w Polsce, jednakże Komisja Edukacji Narodowej została organizowana w znacznej części przez eksjezuitów; oni też, prywatnie lub pod innym niż do 1773 roku patronatem instytucjonalnym, uczestniczyli czynnie w kulturze po 1773 roku, wyznaczając jej kluczowe kierunki.

${ }^{7}$ Zob. B. Wolska, Polityczne aspekty kasaty zakonu jezuitów w poezji czasów sejmu delegacyjnego. W kręgu obiadów czwartkowych: Rzewuski, Naruszewicz, Trembecki o kasacie, „Prace Polonistyczne" 1979, t. 35, s. 53-79; taż, Polityczne aspekty kasaty zakonu jezuitów w poezji czasów sejmu delegacyjnego. Wyniki kasaty w'świetle tej poezji, „Prace Polonistyczne” 1982, t. 38, s. 5-32.

${ }^{8}$ S. Trembecki, Pisma wszystkie, wydanie krytyczne oprac. J. Kott, t. 1, Państwowy Instytut Wydawniczy, Warszawa 1952, s. 122, 124. 
Do praktycznej realizacji dyrektywy Ignacego Loyoli o potrzebie życia „z jedną nogą podniesioną" i domestykacji bycia w podróży jezuici zostali zmuszeni po inwazji Napoleona na Rosję, zwanej też „drugą wojną polską”, która rozpoczęła się 24 czerwca 1812 roku przekroczeniem Niemna przez wojska koalicji. Stało się to kilkanaście dni po uroczystościach oficjalnego wręczenia przywileju ustanawiającego dotychczasowe kolegium jezuickie w Połocku instytucją uniwersytecką. Relację z tej ucieczki przedstawił uczestniczący w niej ksiądz Jan Mihanowicz w niedokończonym, liczącym 790 wersów poemacie Podróż XX. Jezuitów z Połocka do pótnocnej Rosji w roku 1812 przed wejściem wojska francuskiego do Białej Rusi $^{9}$. Adresatem wierszowanego sprawozdania był nieznany bliżej ,przyjaciel”. Na podstawie treści można się jednak domyślić, że autorowi chodziło o świadectwo bardziej uniwersalne niż list poetycki skierowany do jednego odbiorcy. Jezuici w pierwszym okresie swego istnienia (od 1534 do 1773 roku), rozproszeni po całym świecie, nie skąpili pióra dla form sprawozdawczych, pamiętnikarskich i wspomnieniowych, co miało dokumentować ich aktywność i zaangażowanie w życie Kościoła, ale też borykanie się z różnymi zagrożeniami w czasie sprawowanych przez nich misji. Taki właśnie kronikarski wymiar, dotyczący ważnego epizodu z życia zakonników połockich, miała mieć w założeniu Mihanowicza jego relacja.

Informacje o autorze poematu są nader skąpe. Urodził się 27 grudnia 1783 roku w Horspli, wstąpił do Towarzystwa Jezusowego 14 sierpnia 1799 roku, święcenia kapłańskie przyjął w 1811 roku w Połocku, zmarł na gruźlicę 30 stycznia 1814 roku w Witebsku; nauczyciel, poeta, tłumacz, znawca antyku. Uczył się języka niemieckiego w Dyneburgu (1802-1803) oraz języka i literatury greckiej w Połocku (1803-1806) pod kierunkiem Austriaka Jakuba Wissingera, co nie pozostawało bez wpływu na bogaty sztafaż antyczny zastosowany w jego poemacie. Wykładał gramatykę (infimę) i język rosyjski w Orszy (1801-1802), retorykę i poetykę, algebrę i geometrię w Witebsku (1806-1807), architekturę w Połocku (1809-1810). Sprawował ponadto funkcję wychowawcy w konwikcie w Połocku (1807-1808) oraz kaznodziei w Witebsku (1812-1814). Był pierwszym translatorem na język polski tragedii Orestes Eurypidesa. Tłumaczył ponadto Fenicjanki Eurypidesa, Króla Edypa Sofoklesa, pierwszą księgę Iliady oraz z łacińskiego dramat jezuity Gabriela-François Le Jaya Józef w Egipcie ${ }^{10}$.

${ }^{9}$ Archiwum Prowincji Polski Południowej Towarzystwa Jezusowego [APPPTJ] w Krakowie, rkps 285, s. 234-266. Krytyczne wydanie poematu i informacje o autorze w: „O roku ów! kto ciebie widział w naszym kraju!..." Ucieczka jezuitów połockich przed wojskami napoleońskimi w 1812 roku w poetyckiej relacji Jana Mihanowicza SJ, w: Staropolskie i oświeceniowe tematy i preteksty, pod red. J. Kowal, M. Nalepy, R. Magrysia, Wydawnictwo Uniwersytetu Rzeszowskiego, Rzeszów 2016, s. 145-205.

${ }^{10} \mathrm{Na}$ temat realizacji dziejów starobiblijnego Józefa w literaturze polskiej zob. M. M. Kacprzak, Myśl o Bogu i człowieku w „Żywocie Józefa” Mikołaja Reja, Wydział Polonistyki Uniwersytetu Warszawskiego, Warszawa 2003; D. Chemperek, „Castus Joseph” Szymona Szymonowi- 
Pracę nad poematem o exodusie połockich jezuitów przerwał w 1813 roku, jak się można domyślać, wskutek nasilającej się choroby, która dawała o sobie mocno znać w czasie ucieczki z Połocka, na co kilkakrotnie uskarżał się w swojej poetyckiej relacji. Poemat spisywany był zapewne na bieżąco. Po powrocie do Połocka autor uzupełniał go jedynie, korzystając z różnych informatorów historycznych, i cyzelował. Tekst cechuje się poprawnością wierszowania, zaświadcza zatem o dobrym warsztacie poetyckim, a przede wszystkim zmyśle obserwacji autora okraszonym ciętymi i inteligentnymi komentarzami. Mihanowicz okazuje się bowiem utalentowanym i przednim humorystą, korzystającym z różnych technik komicznych: heroicomicum, satyry, żartu, ironii. Realizuje tym sposobem postulat założyciela zakonu o osiąganiu samoświadomości wobec „innych” oraz o dystansowaniu się w stosunku do zaistniałej sytuacji. Humor w obliczu wygnania, nasilającej się choroby i zapuszczania się w obszary, do których nie dotarł kaganiec oświecenia, jest świadectwem dobrego terminowania Mihanowicza w szkole ignacjańskiej. Celuje nim w różne postawy i zachowania chłopów, urzędników i inteligencji rosyjskiej, świętych i duchownych prawosławnych, zakonników franciszkańskich i dominikańskich, ale też w konfratrów jezuickich towarzyszących mu w podróży. Nie szczędzi wreszcie humorystycznych uwag pod swoim adresem. Czasami w tym dystansowaniu się wobec zastanych okoliczności manifestuje Mihanowicz złośliwość, brak wyrozumiałości czy naganę, ale są one powodowane troską oświeconego jezuity o stan ducha i wiedzy poddanych osądowi osób. Tak więc poeta z nieukrywaną pogardą i wyższością, nie tyle jednak pana, ile człowieka cywilizowanego, spogląda na białoruskich i ruskich chłopów. Nie ma dla nich litości. Furmani wciąż są przekonani o fizycznym końcu ziemi i jej płaskości, dlatego ich przymusowej podróży na północ towarzyszy strach, że w każdej chwili niespodzianie mogą spaść w czarną otchłań albo że pod osłoną nocy końmi wjadą w morze, co przyniesie skutki opłakane, jako że nie umieją pływać. Strach ów nie jest udawany, skoro jeden z woźniców uciekł, a inni szykowali się do powrotu (ww. 230-242), jeszcze inny samowolnie zrobił sobie krótką przerwę, przedarł się do Wielkich Łuków, aby obawy egzystencjalne „chłodzić się ruskim czerwonym napojem" (w. 322) i nie myśleć o możliwych konsekwencjach opuszczenia swojej wioski. Ta „samowolka” daje miejscowemu chłopstwu okazję do wyprzężenia koni z jego wozu i „sprzątnięcia” ich „na pewne ustronie” (w. 324).

ca. Problematyka antropologiczna i teologiczna, w: Szymon Szymonowic-poeta wciąż aktualny. Materiaty z sesji naukowej. Zamość 24 października 2008 r., pod red. D. R. Kawałko, Księżnica Zamojska im. Stanisława Kostki Zamoyskiego, Zamość 2008; L. Teusz, „Paralele dwóch świętych Józefów Starego i Nowego Testamentu...” (1749) Jana Kajetana Bernarda Jabłonowskiego a wcześniejsze literackie interpolacje historii Józefa egipskiego w literaturze polskiej, w: W kręgu apokryfów, pod red. E. Jakiela i J. Mosakowskiego, Wydawnictwo Uniwersytetu Gdańskiego, Gdańsk 2015; M. J. Olszewska, „Dzieje Józefa” w komediowym ujęciu Włodzimierza Perzyńskiego, w: Biblia w literaturze polskiej: romantyzm - pozytywizm - Młoda Polska, pod red. E. Jakiela i J. Mosakowskiego, Wydawnictwo Uniwersytetu Gdańskiego, Gdańsk 2013. 
W toku narracji, z rozproszonych tu i ówdzie uwag dowiadujemy się o powodach ucieczki zakonników oraz jej celu. Jezuici opuszczają Połock kilkoma grupami w obstawie żołnierzy, co było poleceniem gubernatora i wolą cara Aleksandra I. Pomimo różnych niedociągnięć, przede wszystkim wynikających z niesłowności chłopów umówionych na transportowanie przewożonego sprzętu, połocczanie są doskonale zorganizowani pod względem logistyki podróży. Zatrzymują się w klasztorach katolickich i prawosławnych, karczmach, gospodach, zajazdach, traktierniach. Chętnie gości ich arystokracja i inteligencja rosyjska, które tym sposobem próbowały wpisywać się w tradycję zachodnioeuropejską - obcowania z jezuitami poczytywanych za emisariuszy oświecenia i ucywilizowania. Dodajmy jednak, iż niektóre przytoczone przez Mihanowicza pytania i komentarze Rosjan przeczą ich aspiracjom do pełnienia funkcji elit intelektualnych i kulturalnych.

Podróż, bo tak przymusową migrację nazywa autor relacji, w rzeczywistości była ucieczką do któregoś z ośrodków zakonnych na północy Rosji - bądź to Dorpatu, bądź Pskowa, tego dokładnie nie wiemy, gdyż relacja Mihanowicza urywa się niespodzianie na opisie przybycia uciekinierów do Nowogrodu Wielkiego. Stało się to pod koniec sierpnia. Relacja obejmuje więc wydarzenia, jakie rozegrały się w ciągu ponad dwu miesięcy. Głównym powodem ucieczki jezuitów połockich nie była li tylko potrzeba ratowania własnej skóry. Dowiadujemy się mianowicie, że wyruszyli z Połocka szesnastoma „gnojowymi wozami” (w. 62, 81) prowadzonymi przez wynajętych chłopów, niewprawionych, jak się okazuje, w długie podróże tego typu, odbywane „pokątnymi dróżkami” zazwyczaj w porze nocnej. W którymś momencie jednak Minahowicz odkrywa rąbka tajemnicy o skrzętnie ukrywanej zawartości pakunków. W czasie gościny u generałowej Ławrowej zakonnik zapomina się i wbrew zarządzeniom zwierzchników ujawnia część ładun$\mathrm{ku}$, który wraz z towarzyszami transportuje:
Nie tylkośmy się tutaj z gośćmi zabawiali,
Lecz też miłych książeczek z tłomoków dostali,
Co dotąd u mnie zwłaszcza były nietykane,
Jak wiatry Ulissesa w worku zawiązane.
(ww. 669-672)

Rozproszone po tekście fragmenty każą przypuszczać, że zakonnicy otrzymali od przełożonych zadanie wywiezienia z Połocka co cenniejszych przedmiotów, wśród nich książek. Możemy domyślać się, iż także paramentów liturgicznych, dzieł sztuki, kolekcji, na przykład minerałów etc. Wiadomo wszakże, że Akademia Połocka była zaopatrzona w cenne eksponaty i pomoce naukowe ${ }^{11}$. Zostały

${ }^{11} \mathrm{O}$ ruchomych dobrach połockich pisze Irena Kadulska, Akademia Połocka. Ośrodek kultury na Kresach 1812-1820, Wydawnictwo Uniwersytetu Gdańskiego, Gdańsk 2004 (rozdz. Muzeum i galeria malarstwa w procesie edukacji i upowszechniania kultury, s. 164-202). Większość 
one przetransportowane do różnych placówek zakonnych, między innymi część zbiorów muzealnych wywieziono do Spasa, gdzie w wyniku prowadzonych działań wojennych uległy całkowitemu zniszczeniu. Najcenniejsze rzeczy wysłano na północ w konwoju, którego uczestnikiem był autor wierszowanej relacji ${ }^{12}$. O materialnym stanie posiadania jezuitów niech świadczy wyposażenie konsekrowanego w 1745 roku kościoła Nawiedzenia NMP w Połocku ${ }^{13}$, gromadzone w okresie od lat sześćdziesiątych XVIII stulecia do początku następnego wieku (zgodnie z zaleceniem Loyoli: „Pochwalać ozdabianie i budowanie kościołów; a także obrazy, które należy czcić z powodu tych osób [świętych], które wyobrażają" [nr 360] $)^{14}$. W latach 1762-1766 w połockiej świątyni wykonano dziewięć ołtarzy z obrazami Szymona Czechowicza oraz organy (autorstwa prawdopodobnie Dominika Adama Caspariniego). Od roku 1783 prace nad ozdobą wnętrza kontynuowali między innymi artyści jezuiccy: Jakub Grym, Jan Wogt, Gabriel Gruber, Franciszek Pryszczyński i Jan Stürmer. W roku 1801 sprowadzono z Werony obrazy Saveria dalla Rosa.

W indeksie sporządzonym przez Konrada Morawskiego, opartym między innymi na opisie inwentarzowym kościoła z 1820 roku, znalazły się ponadto srebrne monstrancje (na przykład ofiarowana przez Stefana Batorego w roku 1583, z herbem wyobrażającym jednogłowego orła $\mathrm{z}$ koroną, inna w promieniach $\mathrm{z}$ koroną i krzyżykiem inkrustowana ponad tysiącem kamieni szlachetnych), pacyfikały, bogato zdobione mszały, srebrne kielichy, krzyże metalowe, relikwiarze, lichtarze, ołtarzyki, lustra, wazony, kariatydy, szaty liturgiczne, obrazy autorstwa jezuickich artystów, ozdobne ramy etc. Zapewne część z tych przedmiotów jezuici wywozili chyłkiem z Połocka latem 1812 roku wraz z innymi kosztownościami, w tym także z cennymi książkami. Ich obawy co do możliwego barbarzyństwa Francuzów po zajęciu Połocka okazały się bowiem w pełni uzasadnione. W krótkim czasie łupem wojska padły jezuickie piwnice, apteki i spiżarnie. Michel Ney zezwolił swoim żołnierzom na niekontrolowany rabunek miasta. Laurent markiz de Gouvion Saint-Cyr, marszałek Francji, kierujący 4. Korpusem, zajął pomieszczenia muzeum fizycznego i teatru, usuwając większość ich wyposażenia, między innymi cenne zbiory historii naturalnej.

Jezuici wracający po kilku miesiącach do Połocka, w tym także Jan Minahowicz, zastali klasztor w opłakanym stanie. Przez kilka dni dezynfekowali zabudo-

z nich, w tym bogaty księgozbiór, została zagrabiona i wywieziona do Petersburga po wypędzeniu jezuitów z Białorusi w 1820 roku.

${ }^{12}$ To, co jezuici próbowali zabezpieczyć przed Francuzami w 1812 roku zostało zagrabione przez Rosjan po roku 1820, m.in. bogata biblioteka uczelniana.

${ }^{13} \mathrm{~K}$. Morawski, Wykaz przedmiotów z kościoła jezuitów w Połocku przetransportowanych w 1843 r. na zamek warszawski, „Hereditas Monasteriorum”2013, vol. 3, s. 337-346.

${ }^{14}$ Św. Ignacy Loyola, Ćwiczenia duchowne, Wydawnictwo WAM, Kraków 2002, http://www. madel.jezuici.pl/inigo/ignacy_cd.htm; dostęp: 2.01 .2016 r. Wszystkie cytaty Ćwiczeń pochodzą $\mathrm{z}$ tego wydania. 
wania dymem z nawozu końskiego, gdyż wskutek niepogrzebanych ciał w mieście rozprzestrzeniła się zaraza.

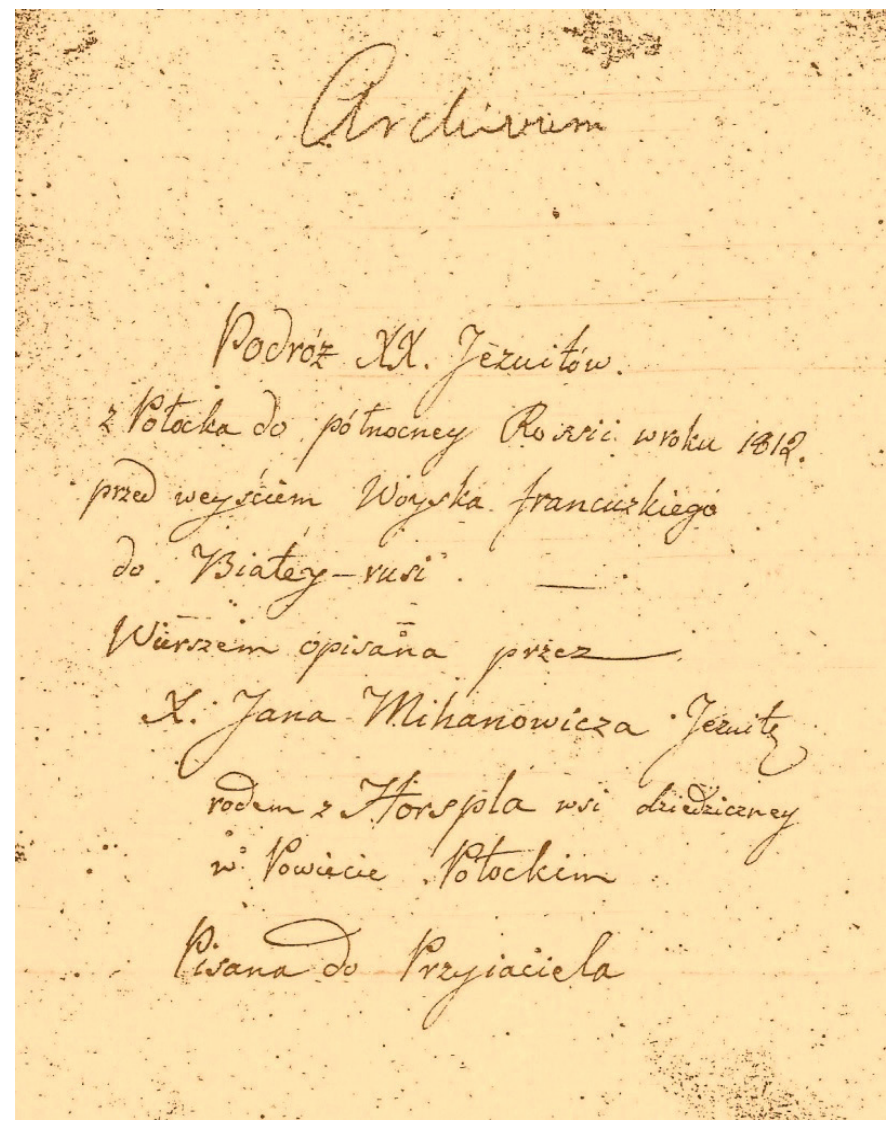

Strona tytułowa nieukończonego poematu Jana Mihanowicza

Jak wcześniej wspomniano, zgodnie z zaleceniami Ignacego Loyoli „rycerz Chrystusowy" powinien bezzwłocznie reagować na zmiany. Szybko więc połocczanie podnieśli się z upadku. Jezuici zresztą z tego słynęli - łatwo się oswajali się z poniesionymi stratami i doznanymi krzywdami. W czasie kilku stuleci działalności zakonu wykształcili zbiorowe i indywidualne umiejętności łatwego przystosowania się do zaistniałej sytuacji. Przeciwności losu pobudzały ich do jeszcze większej aktywności. Tym bardziej dotyczy to jezuitów białoruskich funkcjonujących pod niepewną kuratelą carów moskiewskich. Zatem po wydarzeniach z drugiej połowy 1812 roku Akademia Połocka w krótkim czasie wzbogaciła się o renomowaną kadrę profesorską, powołano sieć placówek filialnych, między innymi w Krasławiu, Mohylowie, Romanowie, Petersburgu, Astrachaniu, 
Rydze, Odessie, w roku 1818 zaczęto wydawać własne czasopismo „Miesięcznik Połocki”. Wraz z innymi współbraćmi rozproszonymi po Rosji i Europie zakonnicy połoccy wzmogli aktywność na rzecz przywrócenia działalności Towarzystwa na całym świecie.

\section{„Radość" - wskrzeszenie - rok 1814}

Statek Towarzystwa rzucany był przez fale i nie ma się czemu dziwić. Nawet łódź Piotra może to dziś spotkać. Noc i władze ciemności są zawsze blisko. Wiosłowanie oznacza wysiłek ${ }^{15}$.

Papież Franciszek I w czasie uroczystych nieszporów sprawowanych z okazji 200-lecia odnowy Towarzystwa Jezusowego

Jak trafnie zauważa Ludwik Grzebień SJ, „Arką dla przetrwania jezuitów stała się wówczas [po 1773 roku - przyp. M. N.] Białoruś - część carskiej Rosji”'16. To tu przybywali z krajów Europy ekszakonnicy Towarzystwa i włączali się w różnorakie prace. Równocześnie czynili starania o restytucję zakonu. Znaleźli w tym względzie sprzymierzeńca, i to nie byle jakiego, bo samego papieża Piusa VII, który najpierw 7 marca 1801 roku potwierdził w breve Catholicae fidei prawne uwarunkowania działalności jezuitów na terenie Rosji, następnie 30 lipca 1804 roku wydał podobny dokument breve Per alias w odniesieniu do Królestwa Obojga Sycylii. Apogeum przychylności papieskiej przypada na 7 sierpnia 1814 roku, kiedy to bullą Sollicitudo omnium ecclesiarum reaktywował zakon na całym świecie, uzasadniając swoją decyzję wolą wielu państw, hierarchów, instytucji i prywatnych osób, czyli posługując się tym samym argumentem, dla którego Klemens XIV Societatis Jesu rozwiązał. W dokumencie z 1814 roku zapisano:

Świat katolicki domaga się jednomyślnym głosem przywrócenia Towarzystwa Jezusowego. Codziennie otrzymujemy wzywające nas do tego i coraz bardziej ponaglające petycje od naszych czcigodnych braci, arcybiskupów i biskupów oraz osób najbardziej zasłużonych, zwłaszcza że obfite owoce, które to Towarzystwo przynosiło w powyższych krajach, były powszechnie znane. Po żarliwej modlitwie wzywając Boskiej pomocy, po wysłuchaniu rad wielkiej liczby naszych Czcigodnych Braci, kardynałów Rzymskiego Kościoła świętego, ogłasza-

${ }^{15}$ „Deon” 27 sierpnia 2014, http://www.deon.pl/religia/serwis-papieski/aktualnosci-papieskie/ art,2339,franciszek-do-jezuitow-wioslujmy-razem.html; dostęp: 22.12.2015 r.

${ }^{16}$ L. Grzebień SJ, Wskrzeszenie zakonu jezuitów, „Życie Duchowe” 2014 (zima), nr 77, s. 73. 
my, z pełną świadomością, na mocy pełni władzy apostolskiej oraz po wieczne czasy, że wszystkie koncesje i uprawnienia przyznane przez nas wyłącznie dla Imperium Rosyjskiego i Królestwa Obojga Sycylii obejmują odtąd wszystkie nasze posiadłości kościelne, a także wszystkie inne państwa. Pozwalamy także i oznajmiamy to, że wolno im [jezuitom] poświęcić się nauczaniu młodzieży i wychowaniu jej w katolickiej wierze i w dobrych obyczajach; mogą więc w sposób wolny i swobodnie objąć w zarząd seminaria i kolegia, i za wiedzą i pozwoleniem miejscowych biskupów słuchać spowiedzi, opowiadać Słowo Boże, udzielać świętych Sakramentów ${ }^{17}$.

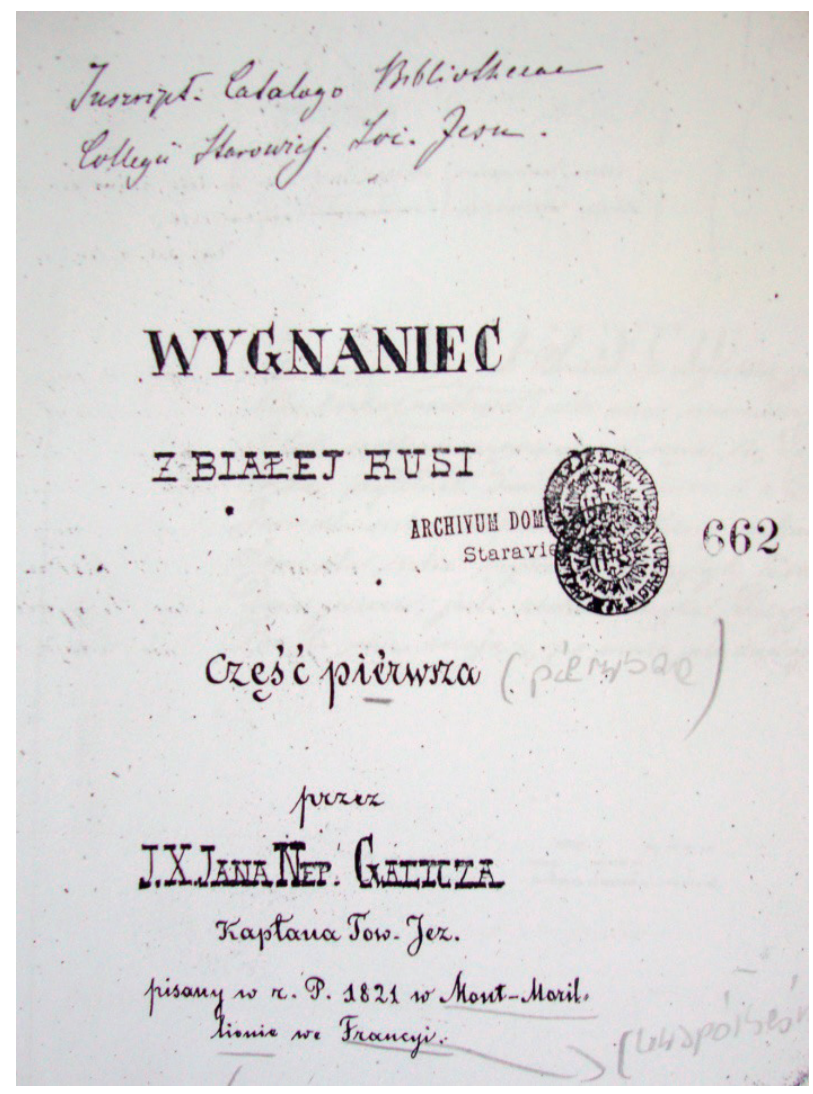

Strona tytułowa Wygnańca z Białej Rusi

\footnotetext{
${ }^{17} \mathrm{http}$ ://jezuici.pl/dziekczynienie-za-wskrzeszenie-tj; dostęp: 22.12.2015 r.
} 


\section{„Troska" - wypędzenie - rok 1820}

Diabeł po bulli wszędzie mieszał, bojąc się [...] o swoje królestwo ciemności.

Tadeusz Brzozowski, generał TJ

I dlatego trzeba nam stać się ludźmi obojętnymi [nie robiącymi różnicy] w stosunku do wszystkich rzeczy stworzonych, w tym wszystkim, co podlega wolności naszej wolnej woli, a nie jest jej zakazane [lub nakazane], tak byśmy z naszej strony nie pragnęli więcej zdrowia niż choroby, bogactwa [więcej] niż ubóstwa, zaszczytów [więcej] niż wzgardy, życia długiego [więcej] niż krótkiego, i podobnie we wszystkich innych rzeczach. (nr 23)

św. Ignacy Loyola

Ignacy Loyola zapytany o to, ile potrzebowałby czasu, aby wrócić do równowagi duchowej, gdyby zakon został rozwiązany, miał bez chwili wahania odpowiedzieć, że wystarczyłby mu kwadrans na modlitwę, po której byłby szczęśliwszy niż kiedykolwiek wcześniej ${ }^{18}$. Założyciel zgromadzenia nie przewidywał u ,rycerzy Chrystusowych" zaistnienia takich stanów ducha jak zwątpienie i żal, nie mówiąc o załamaniu czy rozpaczy. Jezuita miał zachować obojętność wobec niepowodzeń, których doświadczał, oraz gotowość do jeszcze większych wyzwań. To pozwala nam wyjaśnić, dlaczego jezuici - wypędzani po wielokroć, zawieszani w swej działalności, kasowani i poniewierani - są dziś, po 475 latach istnienia, jednym z najliczniejszych, o ile nie najliczniejszym męskim zakonem katolickim.

Carowie rosyjscy, od Iwana Groźnego począwszy, usiłowali ich wykorzystać w swoich międzynarodowych rozgrywkach, od czasów Katarzyny II powierzali im także misję oświecania i cywilizowania Rosji. Gdy ich plany, zwykle wyrachowane i podstępne, napotykały na przeszkody, natychmiast zamykano droge jezuitom do dalszej działalności lub ich wypędzano z imperium. Ci jednak uparcie powracali. Po nieudanej wyprawie Dymitra Samozwańca zabroniono im wstępu na teren Rusi. W roku 1689 roku Piotr I usunął niewielką ich grupę zaniepokojony głosami doradczymi, że mogą w imperium osłabić pozycję prawosławia i wzmocnić katolicyzm. Za niedługi czas postąpił podobnie, argumentując, że jezuici rzekomo wspierali przeciwników cara w sporze o tereny graniczne chińsko-rosyjskie. Pisze Chris Lovney o białoruskich członkach zakonu, których aktywność wzmogła się po 1773 roku:

${ }^{18}$ L. Gonsalves da Cámara, Memoriale czyli Diariusz o św. Ignacym Loyoli 1555, tłum. M. Bednarz SJ, Wydawnictwo WAM, Kraków 1995, nr 182. 
Prawie wiek później dwustu jezuitów, z których większość była rodowitymi Polakami odartymi ze swej narodowej tożsamości przez pierwszy rozbiór Polski, w wyniku najdziwaczniejszego zbiegu okoliczności znalazło się w bezpiecznej przystani - Rosji - dobrze znanej z wyrzucania jezuitów na długo przed tym, zanim to szaleństwo ogarnęło resztę świata. Gdyby władcy Rosji, Austrii i Prus nie podzielili między siebie Polski, likwidacja zakonu zostałaby dokończona. Jakkolwiek tych dwustu nie mogło się już dłużej formalnie nazywać Polakami, to jednak tylko oni mogli się nazywać jezuitami ${ }^{19}$.

W latach 1773-1814 Towarzystwo Jezusowe zachowało swą ciągłość dzięki zakonnikom polskim, którzy musieli balansować na granicy interesu narodowego i zakonnego, niejednokrotnie cele formacyjne stawiając nad interesami zbiorowymi, co miało następstwa w postaci dwuznacznych kalkulacji i rozgrywek politycznych z ich strony. Ważne w nich miejsce zajmowali kolejni po Katarzynie II cesarzowie rosyjscy. Caryca, jak wiadomo, nie podporządkowała się bulli Klemensa XIV z czystej przekory i pozerstwa (terminowała w szkole Woltera i Diderota), ale też doceniała cywilizacyjną funkcję placówek szkolnych prowadzonych na terenie Rosji przez jezuitów. Jej syn Paweł I 11 sierpnia 1800 roku zwrócił się do papieża Piusa VII z prośbą o zatwierdzenie działalności zakonników Towarzystwa Jezusowego na terenie imperium rosyjskiego; przekazał także jezuitom w użytkowanie kościół św. Katarzyny Aleksandryjskiej w Petersburgu, jedną z najstarszych świątyń katolickich w Rosji ${ }^{20}$; snuł plany powierzenia im Akademii Wileńskiej i całego szkolnictwa na Litwie i w Rosji; upatrywał w ,synach Loyoli" przeciwwagę dla nasilającej się aktywności iluministów i masonerii. Wnuk Katarzyny II - Aleksander I zezwolił jezuitom na otwarcie nowych misji na południu i w głębi Rosji, a w 1812 roku, o czym wspomniano na początku, podniósł kolegium w Połocku do stopnia akademii. Zarówno Paweł I jak i Aleksander I usiłowali wykorzystać Societatis Jesu dla prowadzonej przez siebie polityki wewnętrznej. „Szczepowi białoruskiemu” Towarzystwa powierzyli szczególne zadanie - oswajania Polaków z sytuacją, jaka została im narzucona w roku 1795. Miał skutecznie oddziaływać na postawę tego narodu wobec władców rosyjskich i samych Rosjan.

Wraz z przywróceniem działalności jezuitów na całym świecie w 1814 roku administracja rosyjska traciła stopniowo kontrolę nad zakonem, który z wielkim zapałem przystąpił do odbudowania dawnych i tworzenia nowych ośrodków poza granicami imperium carskiego. Pojawili się też wrogowie wewnętrzni, z Towarzystwem Biblijnym na czele. Na konsekwencje tych zmian nie trzeba było długo czekać. Pierwszymi były ukazy carskie o zamknięciu konwiktu petersburskiego w 1815 roku

${ }^{19}$ Ch. Lowney, dz. cyt., s. 261.

${ }^{20} \mathrm{~W}$ kościele został pochowany 12 lutego 1798 r. ostatni monarcha Rzeczypospolitej Stanisław August Poniatowski. 
oraz o wypędzeniu zakonników jezuickich z Petersburga i Moskwy w 1816 roku. Bezpośrednią przyczyną ich wydania miały być kazania głoszone w kościele św. Katarzyny, w których jezuici rzekomo podkreślali wyższość katolicyzmu nad innymi wyznaniami chrześcijańskimi, oraz konwersja bratanka Aleksandra Nikołajewicza Golicyna, ministra do spraw wyznań, która dokonała się w konwikcie petersburskim. Niedługo potem ograniczono zakres działalności dydaktycznej i naukowej Akademii Połockiej.

Rok 1820 rozpoczął się dla jezuitów złowróżbnie. Otóż 5 lutego w Połocku zmarł generał Tadeusz Brzozowski, jedna z ważniejszych postaci Towarzystwa w czasach rozkwitu Połocka i restytucji zakonu. Podobno ostatnim wypowiedzianym przez niego zdaniem miało być ostrzeżenie: „Ja umieram, wy zaś wypędzeni zostaniecie z Rosyi" ${ }^{21}$. Mihanowicz w swoim poemacie nazywa go miłym i troskliwym „o swoje dziatki” ojcem (w. 561), a Stanisław Załęski określa mianem „ostatniego filaru podtrzymującego zakon w Rosji”"22.

Wspomniany wcześniej Aleksander Golicyn przedstawił carowi Aleksandrowi I do podpisania dokument, w którym wymienił argumenty za bezzwłoczną koniecznością wypędzenia jezuitów z imperium rosyjskiego oraz wskazywał na procedurę przejęcia ich majątku. Dokument ów oskarżał zakonników między innymi o łamanie zakazu nawracania na katolicyzm, czego ofiarą mieli paść żydzi, ewangelicy i prawosławni, o wyzysk chłopa białoruskiego, działanie na szkodę państwa, „zasiewanie” niezgody i zamieszania w rodzinach, o chęć wzbogacenia się kosztem Rosjan, nieposłuszeństwo wobec władz, lekceważenie prawa, zły wpływ na uczniów kształcących się w prowadzonych przez Towarzystwo placówkach oświatowych etc. Jak twierdzi Stanisław Załęski, pismo Golicyna zręcznie wykorzystywało kasacyjne breve Klemensa XIV z 1773 roku, a ponadto wzbogacone zostało „zarzutami o prozelityzm i sofistycznymi wywody o niewdzięczności zakonu dla cesarstwa"23. Znawca historii zakonu, Ludwik Grzebień, dodaje, iż:

Prawdziwe przyczyny wypędzenia z Rosji jezuitów w 1820 roku mają trojaki charakter. Po pierwsze, wynikają z reakcji prawosławnej i narodowej Rosji na katolicki prozelityzm jezuitów, następnie z coraz silniejszego dążenia Rosji do podporządkowania sobie szczególnie licznych na Białorusi grekokatolików i wreszcie z manifestowanej wrogości jezuitów do Towarzystwa Biblijnego, wyrażającego religijny synkretyzm Golicyna, którego protestanckie trendy zabarwiały działania polityczne ${ }^{24}$.

${ }^{21}$ S. Załęski, Jezuici w Polsce, t. 5: Jezuici w Polsce porozbiorowej 1773-1905, cz. 1: 1773-1820, Kraków 1906, s. 482.

22 Tamże.

${ }^{23}$ Tamże, s. 493.

${ }^{24}$ L. Grzebień SJ, dz. cyt., s. 74. 
Powołajmy się w tej kwestii na jeszcze jedno stanowisko, mianowicie rzeszowskiego historyka Andrzeja Andrusiewicza, który inaczej tłumaczy decyzję o wypędzeniu jezuitów z Rosji. Twierdzi mianowicie, iż stali się oni kozłami ofiarnymi intryg i spisków, podobnie jak to miało miejsce w przypadku breve kasacyjnego z 1773 roku. Wśród elit rosyjskich zjawisko prozelityzmu rzeczywiście nasiliło się w pierwszych dwudziestu latach XIX wieku. Nie tyle chodziło tu jednak o przebudzenie religijne, ile o rodzaj mody. Katolicyzm zbliżał bowiem Rosjan do ideałów Europy zachodniej. Aleksander I w porozumieniu z Golicynem i ministrem spraw wewnętrznych Osipem Pietrowiczem Kozodawlewem podjął sekretne działania, aby to zjawisko ograniczyć. Role odwróciły się w stosunku do 1773 roku, kiedy Katarzyna ratowała zakon; teraz papież mu sprzyjał, Aleksander I natomiast podpisał dekret banicyjny. Uderzenie w jezuitów nie oznaczało przypuszczenia ataku na katolików w ogóle. Car pragnął bowiem zachować dobre relacje z Piusem VII. „Zamachu na Kościół katolicki w Rosji nie dokonał - pisze dalej Andrusiewicz - a usuwając jezuitów, odsuwał od siebie podejrzenia o potajemne przejście na katolicyzm z inspiracji zakonu"25. Dekret z 13 marca 1820 roku zabraniał członkom Towarzystwa Jezusowego wstępu na teren monarchii rosyjskiej. Ponad dwustu zakonników ${ }^{26} \mathrm{w}$ krótkim czasie musiało opuścić granice imperium.

Ich wypędzenie z Rosji doczekało się, podobnie jak ich ucieczka z Połocka w 1812 roku, swoistej kroniki. Łączy ona cechy form memuarowej i literackiej. Część literacką współtworzą regularne i nieregularne wiersze, nasycone tonami lirycznymi związanymi z poczuciem krzywdy i mentorsko moralnymi, w których do głosu dochodzą oskarżenia o naruszenie praw boskich i ludzkich oraz przekonanie, iż cierpienia doznane przez jezuitów zostaną im w krótkim czasie wynagrodzone, a ich sprawcy - prowokatorzy i donosiciele - zostaną sprawiedliwie rozliczeni. W części pamiętnikarskiej wykorzystano język konkretów, a więc daty, fakty, nazwiska, dokumenty. Niekiedy dla urozmaicenia sprawozdania w tok wywodu włączono anegdoty albo dygresje charakterystyczne dla formy waletowej, implikowane koniecznością opuszczenia „miejsc ukochanych”. Autorem tego dzieła o wymownym tytule Wygnaniec z Białej Rusi ${ }^{27}$ (jego edycję krytyczną przygotowuje akademicki ośrodek w Rzeszowie) był Antoni Nepomucen Galicz (Gallicz, ur. w 1794 roku w Połocku, zm. w 1876 roku w Tarnopolu). Do zakonu wstąpił 8 sierpnia 1810 roku. Nauki pobierał między innymi w dwuletnim Seminarium Nauczycielskim pod kierunkiem znanego pedagoga, poety, dramaturga i teore-

${ }^{25}$ A. Andrusiewicz, Aleksander I. Wielki gracz: car Rosji - król Polski, Wydawnictwo Literackie, Kraków 2015, s. 461.

${ }^{26}$ Inne źródła podają, iż ponad trzystu.

${ }^{27}$ Wygnaniec z Białej Rusi przez J.X. Jana Nep[omucena] Galicza, kaptana Towarzystwa Jezusowego, pisany w r. P. 1821 w Mont-Morillionie we Francji, cz. 1-3, Archiwum Prowincji Polski Południowej Towarzystwa Jezusowego [APPPTJ] w Krakowie, rkps 662. W dalszej części artykułu nieoznaczone cytaty pochodzą z tego źródła. 
tyka literatury ks. Józefa Morelowskiego. W latach 1814-1818 i 1818-1820 uczył w Mohylewie, w latach 1816-1818 studiował filozofię w Akademii Połockiej, a po opuszczeniu Rosji - teologię we Francji. Święcenia kapłańskie przyjął 21 sierpnia 1825 roku. Pełnił funkcje kapelana w Montmorillon, a następnie wychowawcy i rektora w konwiktach szwajcarskich. W środowisku jezuickim uchodził za wybitnego pedagoga i organizatora ${ }^{28}$. Jest autorem instrukcji prawno-administracyjnych dla profesorów i prefektów zatutułowanej Ratio instituendae iuventutis (Chyrów 1903).

Galicz w swoim pamiętniku ${ }^{29}$ zaraz na początku zaznacza, że sporządza go dla użytku wewnętrznego, dla współbraci i że nie powinien on opuścić środowiska jezuickiego. Spisuje go z perspektywy półrocznej, tyle czasu bowiem upłynęło od opuszczenia przez niego Rosji. W wierszowanym wprowadzeniu ocenia dekret Aleksandra I jako rażąco niesprawiedliwy wobec zasług zakonników dla wydźwignięcia imperium z zapaści cywilizacyjnej. Dlatego tułaczkę współbraci porównuje do pasji Chrystusowej, identycznie jak to sto pięćdziesiąt lat wcześniej czynił Zbigniew Morsztyn w Pieśni w ucisku komentującej uchwałę sejmu z 1558 roku, która nakazywała Braciom Polskim opuścić terytorium Rzeczypospolitej. Pisze mianowicie Galicz:

Trapi człeka nieszczęście, gdy się o nim wróży,

Gdy nastaje, gdy ściga; lecz gdy się skończyło,

Weseli się. Już o nim tylko wspomnieć miło.

${ }^{28}$ Zob. T. Bzowski, Wielki wychowawca młodzieży, śp. O.J. Galicz, „Nasze Wiadomości” 1923, nr 6, s. 11-16; K. Drzymała SJ, Wspomnienia naszych zmartych 1820-1982, t. 1, Kuria Prowincji Polski Południowej Towarzystwa Jezusowego, Kraków 1982, s. 12-13; W. Krupiński, Ksiądz Jan Galicz, pedagog jezuicki XIX wieku, Kraków 1996; Encyklopedia wiedzy o jezuitach na ziemiach Polski i Litwy 1564-1995, oprac. L. Grzebień przy współpracy zespołu jezuitów, Wydawnictwo WAM, Kraków 2004; A. Demkowicz, Wypędzenie jezuitów z Imperium Rosyjskiego na podstawie fragmentów ,Wygnańca z Białej Rusi” Jana Galicza, „Tematy i Konteksty” 2012, $\mathrm{nr} 2$ (7): Z archiwum polonisty, pod red. M. Stanisza i Z. Ożoga, Wydawnictwo Uniwersytetu Rzeszowskiego, s. 54-69.

${ }^{29}$ O pamiętnikach Galicza pisze Agata Demkowicz: „Podczas pobytu [Galicz] w Montomorillon, a następnie w Saint-Acheul, a więc w latach 1820-1823, spisywał swoje pamiętniki. Pozostawił trzy tomy wspomnień o następujących tytułach: Wygnaniec z Białej Rusi. Tomik I i II oraz Wygnaniec z Białej Rusi, czyli życie wygnańca z Białej Rusi we Francji. Tomik III. Do czasów współczesnych zachowała się również druga wersja Wygnańca z Białej Rusi. Tomiku I i II. Mowa o Wygnańcu z Białej Rusi, części pierwszej, przez J. Ks. Jana Nep[omucena] Gallicza, kapłana Tow [arzystwa] Jez[usowego] pisanym, w R [oku] P[ańskim] 1821, w Montmorillionie oraz o Wygnańcu z Białej Rusi, części drugiej. Przeprowadzone kwerendy oraz analiza porównawcza obu archiwaliów wykazały, że w przypadku pierwszego z wymienionych tutaj rękopisów (Wygnańca z Białej Rusi. Tomiku I i II) mamy do czynienia z oryginałem. Natomiast Wygnaniec z Białej Rusi, część pierwsza i Wygnaniec z Białej Rusi, część druga jest jego skróconą kopią. Została ona zredagowana przez innego jezuitę, Wojciecha Baudissa, o czym świadczy notatka dołączona na osobnej kartce do strony tytułowej”. A. Demkowicz, dz. cyt., s. 56. 
Czas, Bracia, po półrocznej zmuszonej podróży

Z kraju, wygnańcom spocząć. Obejrzeć się chwilę.

Jak ciężki sąd Boży nas zastał..., a ile

Przemocy w rękę kładzie On przeciwnikowi

Nad Cnotą, kiedy ją raz skusić postanowi.

Aresztują, skazują. A kogo i kiedy?

Twych, Panie, towarzyszy imienia i biedy,

W dzień Wielkiej Środy. Alboż nie tak nam przystało?

Będzież uczeń nad Mistrza? Mistrzowi przed chwałą

Ucierpieć trzeba było. Więcej-eś wziął na się!

Uczniowi dość, że cierpi w jednym z Tobą czasie.

Nie na śmierć nas skazują, nie na biczowanie,

Ciebie odstąpić każą lub obrać wygnanie.

Nie tejże z nami wiary sędzia nas zatraca,

Nie Judasz zaprzedaje, ale nas opłaca.

O!... hańbo! O sromoto!

Trzydziestą srebrnikami Pana oceniono,

Za nas dają złoto!

Łotru niegdyś zrównano, dziś go przeniesiono.

Włóczą Pana po sądach, łżą Go po kryjomu,

Nam bez sądu czytają dekret w naszym domu.

Pan obarczon na górę z krzyżem się pomyka,

Nas najlżej wiozą, a nie bez Cyrenejczyka.

Dziwisz się ludzkości, badasz się przyczyny?

Nie znasz, Bracie, Moskala lub naszej dziedziny.

Pozór to, gdy ci rzekną, już nam świerdzą uszy,

Stare ich prawdy: wiara, Bóg, zbawienie duszy.

Wydali na nas dekret, pozew na szkatuły,

Bogdaj takie znaleźli, jakie się im snuły!

Wszystkośmy zostawili, nie żal nam i teraz.

Wspominamy z weselem i wspomniemy nieraz!

Początek pamiętnika z góry więc narzuca czytelnikowi ocenę postępowania administracji rosyjskiej wobec jezuitów - niesprawiedliwego, niewdzięcznego, pozbawionego tolerancji, ale też rozsądku politycznego. Przy czym Galicz, zgodnie z faktami, za sprawców całego zajścia uznaje ministra Golicyna, a także masońskich zwodzicieli. Przystępuje następnie do szczegółowego opisania tradycyjną formą wspomnieniową (pamiętnik i diariusz) wydarzeń z Wielkiego Tygodnia, które miały miejsce w kolegium mohylewskim, gdzie pamiętnikarz pełnił obowiązki nauczyciela i wychowawcy. Kolegium to działało od 1779 roku, w 1811 roku liczyło 130 uczniów. Jego rektorem w latach 1819-1820 był Dezydery Richardot. 
Problemem kluczowym po wysłuchaniu dekretu Aleksandra I stała się konieczność dokonania wyboru przez zakonników: opuszczenia Rosji lub pozostania na jej terenie, pod warunkiem wszakże podpisania deklaracji lojalistycznej o zmianie zakonu. Ostatecznie jeden z mohylewskich jezuitów (Antoni Werezumski) przystał na drugie rozwiązanie. Autor tłumaczy ów wybór chroniczną melancholią współbrata, która konsekwentnie niszczyła jego duszę i tłumiła heroizm chrześcijański. Reszta zakonników skazała się solidarnie na niepewną tułaczkę.

Przejęcie dóbr mohylewskich dokonało się zgodnie z instrukcją Golicyna. Nad porządkiem, wedle obliczeń Galicza, czuwać miało 46 żołnierzy. „Po obiedzie [w czwartek 25 marca - przyp. M.N.] trzej deputaci z pisarzami, z Żydkiem dla zważenia złota i srebra kościelnego udali się do kościoła. Tam rozpatrywali ubiory, sprzęty zakrystyjne, złote i srebrne wotywki zrywali z świętych obrazów itd.” Autor subtelnie, wykorzystując formę liryczną, napomyka o konflikcie emocjonalnym, który towarzyszy pożegnaniu. Otóż okazuje się, że ignacjańska dyrektywa obojętności i nieprzywiązywania się do ludzi, miejsc i majątku pozostaje w sprzeczności z zaistniała sytuacją, zwłaszcza że towarzyszą jej łzy uczniów, wiernych, znajomych. Daje się wyczuć ton polemiki Galicza z prawodawcą reguły:

Sroga twarz, zbrojny żołnierz, najmniej dziś nas trwoży,

Świętą śmiałość, nie względną daje zakon boży.

Gardzim czczemi pozory i czczym ust odgłosem,

Gardzim poziomym chwały świata tego losem,

Lecz nie chcemy mieć podłą i stałość pozorną,

Twarz stoicką, spokojną, do zmyślania dworną,

Nie czuć żalu, nie płakać, gdy lud płacze wszystek.

Ślepy i nierozsądny męstwa to jest zbytek.

Zbyt trwożliwa roztropność nie zgadza się z stanem:

Znać, czuć, dać przykład - to jest być kapłanem.

$\mathrm{Z}$ drugiej strony autor chcąc uciszyć ów dyskurs wewnętrznych napięć, zdecydowanie deklaruje intencję rycerskiego pogodzenia się z zaistniałą sytuacją, tym bardziej, że wypędzeniu z Mohylewa towarzyszą uroczystości rezurekcyjne i związane z nimi myśli o potrzebie odwagi i konsekwencji w działaniu. „Oprócz tych pokrótce tu wzmiankowanych przykrości wieleśmy jeszcze w tym dniu doświadczyli, lecz wycierpiawszy z Chrystusem, puśćmy one chętnie w niepamięć, pocieszeni chwalebnym jego zmartwychwstaniem". Inną formą pocieszenia dla Galicza jest refleksja nad dekadencjami cywilizacyjnymi związanymi z upadkiem wielkich mocarstw (ubi sunt?) oraz nad dziejami zakonu, na różne sposoby doświadczanemu, także męczeństwem i torturami, a pomimo tego trwającemu i wciąż wypełniającemu powierzoną mu przez Chrystusa misję. Można zaryzykować tezę, że niektóre poetyckie wstawki Galicza są nie tylko komentarzem do 
zaistniałych okoliczności, ale wręcz amplifikacją reguł ignacjańskich, jak na przykład taka oto pobudka:

My zaś, Bracia, bądźmy wierni

Bogu! i w słowie rzetelni!

Nie zrażajmy się przykrością,

Nie zrażajmy się trudnością.

Opuśćmy lube rodziny,

Opuśćmy przodków krainy!

Spieszmy chętnie kędy zorze

Wstaje lub zapada w morze!

Gdzie się thuką Algierczyki,

Gdzie Lapończyk marznie dziki,

Gdzie Tatarzyn łukiem zmierza,

Gdzie ugania Murzyn zwierza

Spieszmy! Trudy Bóg osłodzi,

Smutne czoło rozpogodzi.

Niech nie sidli powab świata,

Niech nie smuci licha strata!

Bo chcąc sięgnąc szczytu Nieba,

Zniżyć się pod krzyżem trzeba!

Nie pociechy, nie swoboda,

Lecz krzyż Pański nam nadgroda.

Ustąp smutku! Niech wesele

Igra niezmiennie na czele!

Bóg jest z nami, niech złość goni!

On swą tarczą nas zasłoni!

Galicz w swoich pamiętnikach, jak już wcześniej odnotowano, odpowiedzialnością za wypędzenie jezuitów z terytorium Rosji obarcza doradców cara i jego urzędników. Podkreśla natomiast, że Aleksander I do końca zachował szlachetność, nawet wtedy gdy zobowiązał administratorów Mohylewa do wyposażenia opuszczających miasto exulantów w podróżną odzież, odpowiednie środki transportu oraz zagwarantowania ich humanitarnego traktowania w ostatnich dniach pobytu w mieście. Miejscowi urzędnicy i prałat opatrznie jednak ową wolę monarchy wypełniali, nie pozwalając zakonnikom odprawiać nabożeństw wielkanocnych i opieczętowując kościół klasztorny.

Nadszedł dzień wyjazdu - 2 kwietnia 1820 roku. W obstawie wojskowej porą wieczorną 12 zakonników opuściło Mohylew. Galicz w pamiętniku potwierdza niejako, że każdy jezuita jest zawsze gotowy do drogi, zawsze ma ,jedną nogę podniesioną”. Pisze tedy w ich imieniu i swoim: „Wybieraliśmy się z ochotą i ra- 
dością, dla miłości Boga, do podróży. Otoczeni smutkiem i płaczem. Okazywały się i u nas łzy, lecz raczej były radości wnętrznej, cierpienia dla Chrystusa Pana, niż smutku zbytecznego znakiem”. Inaczej ta chwila została upamiętniona w wierszowanej walecie. Trudno rozstrzygać, czy występujący w niej ton emocjonalny podyktowany został dystynkcją gatunku czy rzeczywistymi przeżyciami zakonnika.

Zbliża się chwila naszego rozstania,

Tu dla nas będzie miejsce naszego pożegnania.

Tu raz ostatni, a na zawsze pono,

Skupiła miłość nas w życzliwe grono.

Nie zna obłudy, nie zna zwłoki nasza

Wdzięczność, choć zawiść stuoczna zastrasza.

Zwodnicze wieści, rozkaz powtórzony,

Wzmacnia nasz umysł z wami skojarzony.

Nam i wam żołnierz broni użyć głosu!

Widzimy dobrze zewsząd srogość ciosu.

Te łzy, ten widok smutny z okna tego

Będą tłumaczem serca życzliwego.

Niestety! krótka, a ostatnia chwila,

Która nas smutkiem przejętych zasila,

Upływa! Gdy was, o Boże litości,

Zrywa z łon naszych wybieg chytry złości!

Takaż wam wreszcie za trudy zapłata!

Spędzone w pocie tak dziś wieńczą lata!

Pół wieka prawie przez prace i czyny

Zebrane zwiędły w momencie wawrzyny!

Owoż to laury naukowej chwały

Co dotąd kraju głowy uwieńczały,

Płody prac waszych, gdy kraj ozdabiają,

Dziś dla was w smutny cyprys się zmieniają.

Świątynie Pańskie zbroją otoczone,

Domy w rozruchu prawie spustoszone,

Potwarz bez czoła miasta ulicami

Lata, niewinnych zmoczona łzami.

O niewdzięczności podła! zimna dusza!

Co się widokiem takim nie porusza,

Gdy żal nam w sercu dojmuje ponury,

Sam się uśmiecha wypadek natury.

Za kres się prawa niecnota pomyka,

Przecie nie kary, lecz godny pomnika. 
Ścisłym obrębem cnotę określają:

Przyćmić, przytłumić, blask onej żądają!

Wreszcie żegnamy, was wszystkich żegnamy!

Winną na zawsze pamięć oświadczamy.

Ani czas późny, ojciec niepamięci,

Nie zgładzi, co wam wdzięczna miłość święci.

Żegnamy, spieszcie kędy wola Boga

Wzywa. On z wami, nie zasmuci trwoga!

Obce wam kraje, obce wam narody,

Gotują za nas obfite nadgrody.

Nam zaś dopóki stać będą świątynie

Bez was, wdzięczności łza nieraz wypłynie.

Wam pamięć winna nasza nie ustanie,

Póki w śmiertelnych członkach życie stanie.

Kolejne karty pamiętników wypełniają szczegóły podróży, których ważną część stanowi fragment dotyczący przyjęcia zakonników na terytorium monarchii austriackiej. Opis przekroczenia kordonu granicznego kończy też pierwszą część wspomnień.

Większość z ponad 200 jezuitów wypędzonych z Rosji osiadła w Galicji, gdzie powierzono im parafie i organizację szkolnictwa. Galicz przez Włochy dostał się do Francji. „Część rosyjska” jego tekstu oddzielona jest od „części austriackiej” kolejnym płaczliwym pożegnaniem, tym razem ojczyzny, któremu towarzyszy powtarzający się refren. Zapewne miał tu na myśli autor nie Rosję czy Polskę, ale rodzinną Białoruś:

Żegnam Cię, Ojczyzno miła!

Jużem na obcej ziemi.

Obyś się mi znów wróciła

Z towarzyszy mymi!

W pamiętniku mohylawianina brakuje tego, co było solą poematu Mihanowicza: humoru o różnych odcieniach, ciętego języka, dobrego rozeznania, czyli - zamanifestowania niebanalnej inteligencji. Galicz jest liryczny, elegijny, refleksyjny, mentorski, trochę zgnuśniały, złośliwy jedynie w stosunku do masonów, zawsze poprawny, a tym samym niekiedy nudnawy, gdy idzie o wartość lekturową jego pamiętnika. Obydwa zapisy są natomiast nieprzecenione pod względem poznawczym. Wzbogacają o ważne wątki zarówno historię zakonu, jak i historię Kresów narodowych. Z pamiętnika Mihanowicza dowiadujemy się na przykład, że nie każdy Polak zamieszkujący tereny na wschód od Bugu czy Niemna z utęsknieniem czekał na Napoleona, do czego usiłował przekonać czytelnika Adam Mickiewicz 
w swoim arcypoemacie, z kolei pamiętniki Galicza stanowią coś na kształt „eneidy” białoruskich jezuitów, którzy po utracie ,ilionów” rozpraszają się w poszukiwaniu „nowych troi” dla siebie i zgromadzenia. Obydwa zapisy pokazują też, jak duży wpływ na postrzeganie świata przez zakonnika jezuickiego miała duchowość ignacjańska, w kontekście której należy rozpoznawać i oceniać jego aktywność, stosunek do Kościoła, do innowierców, także, a może przede wszystkim do spraw narodowych, w tym do polityki carów moskiewskich. Formacyjność zakonna stanowi klucz do odczytania uwag i komentarzy zarówno trzydziestoletniego księdza Jana Mihanowicza, jak i dwudziestosiedmioletniego Jana Galicza.

Interesujący z tego punktu widzenia jest wspomniany wyżej zapis dotyczący Antoniego Werezumskiego, który jako jedyny spośród jezuitów mohylewskich podpisał w marcu deklarację o pozostaniu w Rosji. Galicz unika oceny jego zachowania, ale tylko pozornie, bo komentarz wkłada w usta innych. Zakonnik zostaje okrzyknięty zdrajcą przez katolickich obywateli miasta związanych z jezuitami oraz przez młodzież uczącą się w miejscowym kolegium. Ostro reagują oni na decyzję Werezumskiego, nie przebierając w słowach. Te najbardziej wyszukane i wulgarne autor przemilcza. Cytuje jedynie okrzyki, jakie w jego stronę kierowała młodzież szkolna: „Nie warteś sukienki św. Ignacego, boś niestały! Nie dotrzymałeś słowa danego Bogu! Nie warteś szacunku, boś wiarołomny!”. Galicz stara się zrozumieć zachowanie współbrata. Powody dokonania takiego, a nie innego wyboru w obliczu administracyjnego ultimatum znajduje w obcej duchowi jezuickiemu melancholii, zaznaczając, że brat Werezumski od dawna na nią cierpi. Stan ten nasilił się po wkroczeniu do klasztoru żołnierzy i służby cywilnej. Werezumski zachowywał się wówczas jak nieprzytomny; „samotny ocierał o kąty”, odmawiał posiłku i towarzystwa z konfratrami. Sporządzony przez Galicza indeks objawów chorobowych żywo przypomina acedię kojarzoną w środowiskach klasztornych z lenistwem duszy, zniechęceniem, wyczerpaniem. Takie wyjałowienie, zdaniem pamiętnikarza, prowadzi do braku kontroli nad sobą, a stąd do złych wyborów i grzechu, z apostazją włącznie. Usiłuje więc przez perswazję zmienić jego nastawienie do świata, zgodnie z ignacjańskimi zaleceniami, tym razem nadając im formę wierszowaną:

Już nam siódme słońce wschodzi,

Jak w żałośnej łez powodzi,

Otoczeni smutkiem w koło,

Nucim Panu pieśń wesoło.

I zbrojny żołnierz przy boku

Nie zrazi nam blaskiem wzroku

Ani stooczne Argusy,

Ani złośliwych serce musy.

W kole braci pędzim mile 
Wolne od kłopotów chwile.

Patrz, jak się raduje dusza,

Złością, krzywdą się nie wzrusza!

Ty zaś, kryjesz swe układy,

Rumianyś, w moment wnet blady!

Choryś, zdrowyś jednej chwili,

Natura się w tobie sili.

Co znaczy ta twarz ponura?

Jakaż zasępiła chmura

Trosk czoło? Przecz mi z widoku

Zmykasz, a zaglądasz z boku?

Wszystkoć się w gorycz obraca,

Ni spoczynek, ani praca

Twych rozpędzić trosk nie zdoła.

Zmykasz z braterskiego koła.

Już nie smakująć potrawy,

Pościsz dzień trzeci dla sprawy.

Jakiej? Powiedz mi rzetelnie!

Ten co pyta, sprzyjać wiernie.

Nie opowiadasz mi słowa!

Czoło smutne, jasna mowa.

Upadłeś, niebaczny pono!

Już braci niemiłeć grono!

„Upadłem!” - mówisz mi śmiało,

Dobrze lub źle, już się stało.

Choćbym się chciał zrzec wyroku,

Podpis broni cofnąć kroku.

Znosić trudy i potwarze,

Nie wszystkim Bóg daje w darze.

Mi nie siła, ni chęć służy.

Żegnam! Nie wydołam dłużej!"

Spiesz więc, chęcią zaślepiony,

Zwiedz powabne świata strony!

Zażyj uciech! Żyj swobodno,

Boć pod krzyżem niewygodno.

Nie zajrzę ci, nie winszuję,

Przeto cię tylko żałuję,

Żeś na chlebie pańskim lata

Pędząc, tęsknił do dóbr świata!

Spiesz więc, mój miły Antoni,

Jan za tobą nie pogoni. 
Gorycz i strach i ciasnota,

To mi zaszczyt, to mi cnota!

Spiesz, lecz pomyśl o tym przecie,

Że nie ma szczęścia na świecie.

I pociecha, i kwiat wieku,

Niedługo trwają przy człeku!

Spiesz! lecz służ w bojaźni Bogu!

Pomyśl, żeś w wieczności progu,

Pomyśl, żeć ziemia gospodą,

Wieczność karą lub nadgrodą!

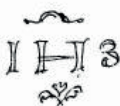 \\ E X E R C I T I A}

S PIRITVALIA.
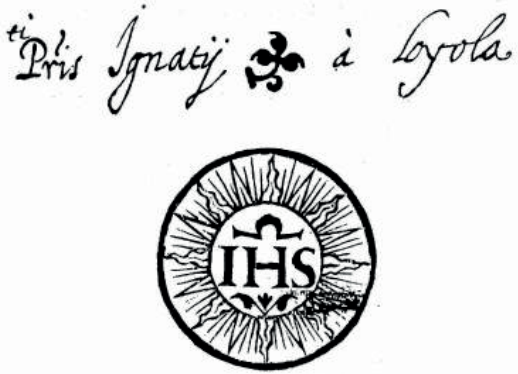

M. D, XLVIII,

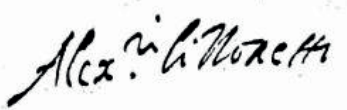

Pierwsza strona wydania Ćwiczeń duchownych Ignacego Loyoli z 1548 roku

W Ćwiczeniach duchownych Ignacego Loyoli „melancholia” nazwana jest „strapieniem”. Mowa tutaj o takich jej objawach, jak „,ciemność w duszy”, „,zakłócenie w niej”, zbytnia troska o rzeczy doczesne, nieufność, brak nadziei i miłości, lenistwo duchowe, obojętność, oziębłość, smutek, „odłączenie od swego Stwórcy i Pana" (nr 317-325). Galicz zaleca Werezumskiemu, aby w zaistniałej sytuacji nie silił się na żadne zmiany. Podobnie radził swoim „synom” Loyola, twierdząc, że w czasie strapienia nie należy odstępować od wcześniejszych postanowień (nr 319). W pocieszeniu bowiem strażnikiem zakonnika jest dobry duch, w strapieniu - zły, 
w związku z tym przy radach i podszeptach tego ostatniego nie ma możliwości wejścia na dobrą drogę. Należy więc jedynie, do czego zachęca Galicz, starać się przez modlitwę, rozmyślanie, rachunek sumienia i pokutę zmienić siebie i swoje nastawienie do strapienia. Przede wszystkim trzeba zaś zachować cierpliwość, która jest antidotum na konsekwencje złych zmian. Owe zalecenia Galicza, kierowane w stronę brata zakonnego, są także, jak można się domyśleć, autoanalizą własnego strapienia, wynikającego z konieczności opuszczenia Białorusi. Trzecia ignacjańska racja wyjaśnia podobny smutek tym, że Bóg, doświadczając człowieka strapieniem, chce dać „prawdziwe poznanie i uświadomienie sobie, tak iż byśmy to wewnętrznie odczuli, że nie w naszej mocy jest zdobyć i zatrzymać wielką pobożność, silną miłość, łzy czy też inne jakie pocieszenie duchowe, lecz że to wszystko jest darem i łaską Boga, Pana naszego, i żebyśmy nie panoszyli się w cudzym gnieździe, podnosząc się rozumem do jakiejś pychy czy próżnej chwały i przypisując sobie pobożność lub inne jakieś skutki pocieszenia” (nr 322). Ignacy Loyola podkreśla, że „chrystusowy rycerz” nie przywiązuje się ani do stanu strapienia, ani do radości: „Będący w okresie pocieszenia niech się stara upokorzyć i uniżyć, ile tylko może, myśląc o tym, jak niewiele może w czasie strapienia bez takiej łaski i pocieszenia. I przeciwnie, ten, co jest w okresie strapienia, niech myśli, że wiele może z łaską wystarczającą do stawiania oporu wszystkim swoim nieprzyjaciołom, czerpiąc siły w Stwórcy i Panu swoim” (nr 324). Treść całej wierszowanej konsolacji Galicza doskonale rozwija to ostatnie zalecenie ${ }^{30}$.

I jeszcze jedna uwaga na koniec. Zarówno Minahowicz, jak i Galicz, pomimo iż deklarują prywatny charakter napisanych przez siebie utworów, milczą o sprawach narodowych; ich refleksy co najwyżej można odczytać w treściach implikowanych. Zastanawia natomiast podobieństwo obu tekstów w ocenie Aleksandra I. O ile Mihanowicz miał ku temu racje wynikające z sytuacji politycznej w 1812 roku i z pomocy cara udzielonej zakonnikom uciekającym z Połocka, o tyle w przypadku wydarzeń opisywanych przez Galicza imperator był ostatecznym sprawcą banicji jezuitów. Pomimo to zakonnik (nie jest on, co prawda, czołobitny jak na przykład Morelowski) stroni od krytycznych uwag na temat cara, i - pomimo elegijno-rozrachunkowego tonu pamiętników - nie kieruje swych żalów pod jego adresem. To dwuznaczne, gdy idzie o etykę narodową, stanowisko - i w ogóle stanowisko jezuitów białoruskich wobec carskich sprawców nieszczęść Polaków - pozwala nam zrozumieć po raz kolejny duchowość ignacjańska. Jedna z reguł Ćwiczeń duchowych zachęca do ostrożności w podejmowaniu krytyki przełożonych - tak konsekrowanych, jak i świeckich:

${ }^{30}$ Zob. też: S. Grygiel, Sens cierpienia w przemijajacym świecie, w: Jezuicka „,ars educandi”. Prace ofiarowane Księdzu Profesorowi Ludwikowi Piechnikowi SJ, pod red. M. Wolańczyk i S. Obirka SJ, Wydawnictwo WAM, Kraków 1995, s. 79-94. 
Winniśmy być bardziej gotowi do uznawania i pochwalania tak dekretów i zarządzeń, jak i obyczajów naszych przełożonych [niż do ich ganienia]. Bo chociaż niekiedy nie są one lub nie były takie [tj. godne pochwały], to jednak mówienie przeciw nim czy to publicznie w kazaniach, czy w rozmowach z ludźmi prostymi, rodziłoby więcej szemrania i zgorszenia niż pożytku. Lud bowiem oburzałby się na swych przełożonych czy to świeckich, czy duchownych. Ale jeśli powoduje się szkodę, krytykując przed ludźmi prostymi przełożonych w ich nieobecności, to może być rzeczą pożyteczną mówić o tych złych obyczajach do tych tylko osób, które mogą temu zaradzić.

(nr 362)

\section{Bibliografia}

\section{Podmiotowa}

Kochanowski Jan, Pieśń IX z Ksiagg wtórych, w: tegoż, Pieśni, wstęp i oprac. L. Szczerbicka-Ślęk, wyd. 6, Zakład Narodowy im. Ossolińskich - Wydawnictwo Polskiej Akademii Nauk, Wrocław 2008, BN I, nr 100, s. 79.

Loyola Ignacy św., Ćwiczenia duchowne, Wydawnictwo WAM, Kraków 2002, http://www.madel. jezuici.pl/inigo/ignacy_cd.html; dostęp: 2.01.2016 r.

Mihanowicz Jan, Podróż XX. Jezuitów z Połocka do pótnocnej Rosji w roku 1812 przed wejściem wojska francuskiego do Białej Rusi, Archiwum Prowincji Polski Południowej Towarzystwa Jezusowego [APPPTJ] w Krakowie, rkps 285.

Trembecki Stanisław, Oda na ruinę zakonu jezuitów, 1773, w: tegoż, Pisma wszystkie, wydanie krytyczne oprac. Jan Kott, t. 1, Państwowy Instytut Wydawniczy, Warszawa 1952, s. 122-124.

Wiersze Józefa Morelowskiego, wyd. i wstęp oprac. E. Aleksandrowska, Zakład Narodowy im. Ossolińskich - Wydawnictwo Polskiej Akademii Nauk, Wrocław 1983, Zapomniani Poeci Oświecenia, [t. 2].

Wygnaniec z Białej Rusi przez J.X. Jana Nep[omucena] Galicza, kapłana Towarzystwa Jezusowego, pisany w r. P. 1821 w Mont-Morillionie we Francji, cz. 1-3, Archiwum Prowincji Polski Południowej Towarzystwa Jezusowego [APPPTJ] w Krakowie, rkps 662.

\section{Przedmiotowa}

„Deon” 27 sierpnia 2014, http://www.deon.pl/religia/serwis-papieski/aktualnosci-papieskie/art,2339,franciszek-do-jezuitow-wioslujmy-razem.html; dostęp: 22.12 .2015 r.

Andrusiewicz Andrzej, Aleksander I. Wielki gracz: car Rosji - król Polski, Wydawnictwo Literackie, Kraków 2015.

Bzowski Teofil, Wielki wychowawca młodzieży, śp. O.J. Galicz, „Nasze Wiadomości” 1923, nr 6, s. 11-16.

Chemperek Dariusz, „Castus Joseph” Szymona Szymonowica. Problematyka antropologiczna i teologiczna, w: Szymon Szymonowic - poeta wciaż aktualny. Materiały z sesji naukowej. Zamość 24 października 2008 r., pod red. D. R. Kawałko, Księżnica Zamojska im. Stanisława Kostki Zamoyskiego, Zamość 2008, s. 55-63.

Demkowicz Agata, Wypędzenie jezuitów z Imperium Rosyjskiego na podstawie fragmentów „,Wygnańca z Białej Rusi” Jana Galicza, „Tematy i Konteksty” 2012, nr 2 (7): Z archiwum polonisty, pod red. M. Stanisza i Z. Ożoga, Wydawnictwo Uniwersytetu Rzeszowskiego, s. 54-69.

Drzymała Kazimierz SJ, Wspomnienia naszych zmarlych 1820-1982, t. 1, Kuria Prowincji Polski Południowej Towarzystwa Jezusowego, Kraków 1982, s. 12-13. 
Encyklopedia wiedzy o jezuitach na ziemiach Polski i Litwy 1564-1995, oprac. L. Grzebień przy współpracy zespołu jezuitów, Wydawnictwo WAM, Kraków 2004.

Gonsalves da Cámara Ludwik, Memoriale czyli Diariusz o św. Ignacym Loyoli 1555, tłum. Mieczysław Bednarz SJ, Wydawnictwo WAM, Kraków 1995, nr 182.

Grygiel Stanisław, Sens cierpienia w przemijajacym świecie, w: Jezuicka ,ars educandi”. Prace ofiarowane Księdzu Profesorowi Ludwikowi Piechnikowi SJ, pod red. M. Wolańczyk i S. Obirka SJ, Wydawnictwo WAM, Kraków 1995, s. 79-94.

Grzebień Ludwik SJ, Wskrzeszenie zakonu jezuitów, „Życie Duchowe” 2014 (zima), nr 77, s. 73.

http://jezuici.pl/dziekczynienie-za-wskrzeszenie-tj; dostęp: $22.12 .2015 \mathrm{r}$.

Kadulska Irena, Akademia Połocka. Ośrodek kultury na Kresach 1812-1820, Wydawnictwo Uniwersytetu Gdańskiego, Gdańsk 2004.

Kacprzak Marta M., Myśl o Bogu i człowieku w „Żywocie Józefa” Mikołaja Reja, Wydział Polonistyki Uniwersytetu Warszawskiego, Warszawa 2003.

Krupiński Wiesław, Ksiądz Jan Galicz, pedagog jezuicki XIX wieku, Kraków 1996.

Litak Stanisław, Jezuici na tle innych zakonów męskich w Polsce $w$ XV-XVIII wieku, w: Jezuici a kultura polska. Materiały sympozjum z okazji Jubileuszu 500-lecia urodzin Ignacego Loyoli (1491-1991) i 450-lecia powstania Towarzystwa Jezusowego (1540-1990), Kraków, 15-17 lutego 1991 r., pod red. L. Grzebienia SJ, S. Obirka SJ, Wydawnictwo WAM, Kraków 1993, s. $185-199$.

Lowney Chris, Heroiczne przywództwo. Tajemnice sukcesu firmy istniejącej ponad 450 lat, tłum. Łukasz Malczak, Wydawnictwo WAM, Kraków 2011.

Morawski Konrad, Wykaz przedmiotów z kościoła jezuitów w Połocku przetransportowanych w 1843 r. na zamek warszawski, „Hereditas Monasteriorum” 2013, vol. 3, s. 337-346.

Nalepa Marek, „O roku ów! kto ciebie widział w naszym kraju!...” Ucieczka jezuitów połockich przed wojskami napoleońskimi w 1812 roku w poetyckiej relacji Jana Mihanowicza SJ, w: Staropolskie i oświeceniowe tematy i preteksty, pod red. J. Kowal, M. Nalepy, R. Magrysia, Wydawnictwo UR, Rzeszów 2016, s. 145-205.

Olszewska Maria Jolanta, „Dzieje Józefa” w komediowym ujęciu Włodzimierza Perzyńskiego, w: Biblia w literaturze polskiej: romantyzm - pozytywizm - Młoda Polska, pod red. E. Jakiela i J. Mosakowskiego, Wydawnictwo Uniwersytetu Gdańskiego, Gdańsk 2013, s. 79-101.

O'Malley John SJ, To Travel to Any Part of the World: Jerónimo Nadal and the Jesuit Vocation, "Studies in the Spirituality of Jesuits 16" 1984, nr 2.

Skarb Kościoła. „Ćwiczenia duchowe” w praktyce, praca zbiorowa pod red. T. Hajduka SJ, Wydawnictwo WAM, Kraków 2000.

Teusz Leszek, , Paralele dwóch świętych Józefów Starego i Nowego Testamentu...” (1749) Jana Kajetana Bernarda Jabłonowskiego a wcześniejsze literackie interpolacje historii Józefa egipskiego w literaturze polskiej, w: W kręgu apokryfów, pod red. E. Jakiela i J. Mosakowskiego, Wydawnictwo Uniwersytetu Gdańskiego, Gdańsk 2015, s. 75-92.

Wolska Barbara, Polityczne aspekty kasaty zakonu jezuitów w poezji czasów sejmu delegacyjnego. W kręgu obiadów czwartkowych: Rzewuski, Naruszewicz, Trembecki o kasacie, „Prace Polonistyczne" 1979, t. 35, s. 53-79.

Wolska Barbara, Polityczne aspekty kasaty zakonu jezuitów w poezji czasów sejmu delegacyjnego. Wyniki kasaty w świetle tej poezji, „Prace Polonistyczne” 1982, t. 38, s. 5-32.

Załęski Stanisław SJ, Historia zniesienia jezuitów w Polsce i ich zachowanie na Białej Rusi, t. 2, Lwów 1875.

Załęski Stanisław, Jezuici w Polsce, t. 5: Jezuici w Polsce porozbiorowej 1773-1905, cz. 1: 1773-1820, Kraków 1906. 


\section{Marek Nalepa}

\section{Excerpts from the history of Belarusian Jesuits}

\section{(Summary)}

Empress Catherine II ignored Pope Clement XIV 's suppression brief from 1773 and preserved the Belarusian branch of the Society of Jesus. The article draws attention to three important events in the history of this group: the Napoleonic campaign of 1812, restoration of the Order worldwide in 1814 and expulsion from Russia in 1820. These events are documented in sources which are discussed in the paper: an unfinished poem by Jan Mihanowicz, SJ, entitled Podróż XX. Jezuitów z Połocka do pótnocnej Rosji w roku 1812 przed wejściem wojska francuskiego do Białej Rusi (The Trip of Jesuit Priests from Polotsk to Northern Russia in 1812 before the Advance of the French Army to Bela Rus) and the diaries of Jan Galicz, SJ, Wygnaniec z Biatej Rusi (An Exile from Bela Rus).

Keywords: Jesuits; Ignatius of Loyola; Polotsk; Mohylew; Alexander I; Mihanowicz; Galicz, diaries Słowa kluczowe: jezuici; Ignacy Loyola; Połock; Mohylew; Aleksander I; Mihanowicz; Galicz; pamiętniki 